\title{
A PCR-based Assay for Detection of Alternaria radicina on Carrot Seed
}

\author{
B. M. Pryor and R. L. Gilbertson, Department of Plant Pathology, University of California, Davis 95616
}

\begin{abstract}
Pryor, B. M., and Gilbertson, R. L. 2001. A PCR-based assay for detection of Alternaria radicina on carrot seed. Plant Dis. 85:18-23.

A pair of polymerase chain reaction (PCR) primers was developed based upon the sequence of a cloned random amplified polymorphic DNA (RAPD) fragment of Alternaria radicina, and a PCR-based seed assay was developed for the detection of $A$. radicina from infested carrot seed. The seed assay involved a 5-day incubation step, in which seed was maintained under high humidity conditions in order to increase fungal biomass. Seed was then incubated with lysis buffer, extracted with phenol-chloroform, and DNA was recovered using a silica matrix. PCR amplification of the target $A$. radicina DNA sequence was enhanced by the addition of skim milk to the PCR reaction mixture. With this PCR-based seed assay, A. radicina was detected from carrot seed lots with natural infestation rates as low as $0.3 \%$. In seed lots prepared by mixing known amounts of $A$. radicina-infested seed with noninfested seed, this assay allowed for the detection of the pathogen from lots with infestation rates as low as $0.1 \%$.
\end{abstract}

Additional keywords: black rot of carrot, Daucus carota, seedborne pathogen

Alternaria radicina Meier, Drechs., and Eddy, causal agent of black rot disease of carrot (Daucus carota L.), is an important carrot pathogen found worldwide wherever carrots are commercially produced $(4,14)$. The fungus is primarily a root pathogen and causes dry, black, necrotic lesions on the carrot crown and root. These lesions may expand and coalesce, rotting the entire carrot root. Black rot is most severe on carrots maintained in cold storage, but also occurs on mature carrots in the field $(10,12)$. Under favorable conditions, $A$. radicina also can cause damping-off of seedlings, a foliar blight, or both $(5,12$, 15,16).

Carrot umbels and seed are readily infected by $A$. radicina and the fungus is a common pathogen of carrot seed $(6,16,29)$. For example, $99 \%$ of 313 commercial seed lots assayed for A. radicina in Poland from 1984 to 1988 were contaminated, with levels of infestation ranging from 0.5 to $82.5 \%$ (29). Floral infections can result in reduced seed production, and seed infection can result in reduced seed germination, reduced vigor, contamination of seed, or a combination of symptoms $(6,16,29)$.

Corresponding author: R. L. Gilbertson E-mail: rlgilbertson@ucdavis.edu

This work was partially supported by the California Fresh Carrot Advisory Board, the StorkanHanes Research Foundation, and the College of Agricultural and Environmental Sciences, University of California, Davis.

Accepted for publication 30 August 2000.

Publication no. D-2000-1020-02R

(c) 2001 The American Phytopathological Society
The planting of infested seed can result in the introduction of $A$. radicina into carrot fields or production areas $(19,21,24)$. Once introduced, the fungus can survive in soil for years, even in the absence of carrot production $(5,12,13,21)$.

The use of pathogen-free seed (i.e., seed tested to be free of the pathogen) is an essential component of an integrated management strategy for carrot black rot, although there are no universally accepted tolerance levels for seed infestation. The most common method of testing seed is the freezer-blotter assay, in which seed is placed on moistened blotter paper, frozen to arrest germination, and then incubated for 10 days at $20^{\circ} \mathrm{C}$ to allow fungal growth and sporulation $(7,8,17,27)$. Seeds are examined microscopically for $A$. radicina conidia. However, conidia of $A$. radicina are similar in size and morphology to those of a number of related Alternaria, Ulocladium, and Stemphylium spp., some of which are common saprobes on carrot seed. This can make it technically difficult and time consuming to precisely identify A. radicina on carrot seed with the freezerblotter method.

Advances in molecular biology, particularly the polymerase chain reaction assay (PCR), have provided exciting opportunities for the development of rapid and precise nucleic acid-based tests for the detection of seedborne pathogens. PCRbased seed assays have been developed for the detection of various plant pathogens on or in seed, including plant pathogenic bacteria associated with bean (1), carrot (30), and cereal and grass seed (11), and viruses in seed of lupine (2), lettuce (31), and pea (18). To date, relatively few such assays have been developed for detection of seed- borne fungi. PCR-based assays have been developed for the detection of Tilletia indica teliospores recovered from wheat seed and for detection of highly virulent strains of Leptosphaeria maculans on rape seed (26,28).

The objective of this research was to develop a relatively simple PCR-based assay for the detection of seedborne $A$. radicina that could be used by the carrot seed industry. A short report of this research has appeared in abstract form (22).

\section{MATERIALS AND METHODS}

Fungus isolates and seed lots. Isolates of A. radicina, A. dauci, and A. alternata used in this study (Table 1) were recovered from commercial carrot seed lots. Isolates of $A$. radicina included the morphologically distinct types 1 and 2 (20). The sources of the other fungal isolates used are listed in Table 1. Cultures were grown on potato dextrose agar (PDA; Difco Laboratories, Plymouth, $\mathrm{MN}$ ) or cornmeal agar (CMA, Difco Laboratories) plates at $22^{\circ} \mathrm{C}$, and stored on PDA slants at $5^{\circ} \mathrm{C}$. Each isolate was identified based upon standard morphological criteria, comparison with type cultures, or both.

Nine commercial carrot seed lots, designated A to I, were used in this study. Based on freezer-blotter assays of 1,000 seeds/lot, these lots were naturally infested with $A$. radicina at levels of 1.0, 11.5, 8.0, 41.3, $6.5,0.3,0.0,0.0$, and $0.0 \%$ for lots $\mathrm{A}$ through I, respectively. These seed lots also were naturally infested with saprobic fungi including Alternaria (mostly A. alternata), Ulocladium, and Stemphylium spp.

DNA isolation. Liquid cultures were prepared by flooding agar plates (PDA or CMA) containing 10-day-old cultures of test fungi with $10 \mathrm{ml}$ of sterile deionized $\mathrm{H}_{2} \mathrm{O}$ and dislodging mycelia and conidia with a plastic rod. The suspension $(2 \mathrm{ml})$ was added to $100 \mathrm{ml}$ of sterile liquid growth medium (20.7 $\mathrm{g}$ of D-glucose, $1.2 \mathrm{~g}$ of DL-asparagine, $1.2 \mathrm{~g}$ of $\mathrm{K}_{2} \mathrm{HPO}_{4}, 0.5 \mathrm{~g}$ of $\mathrm{MgSO}_{4} \cdot 7 \mathrm{H}_{2} \mathrm{O}, 0.5 \mathrm{~g}$ of yeast extract, and $0.1 \mathrm{~g}$ of $\mathrm{NaCl}$ per liter) in a $250-\mathrm{ml}$ Erlenmeyer flask and flasks were shaken on a rotary shaker at $120 \mathrm{rpm}$ for 3 to 5 days at $22^{\circ} \mathrm{C}$. Mycelia were harvested by filtration through Miracloth (Calbiochem, San Diego, CA), lyophilized, and stored desiccated at $-20^{\circ} \mathrm{C}$.

For each extraction of fungal total genomic DNA, $100 \mathrm{mg}$ of lyophilized mycelia were ground into a powder in liquid $\mathrm{N}_{2}$ with a mortar and pestle. Lysis buffer ( $2 \mathrm{ml})(10 \mathrm{mM}$ Tris-HCl, $\mathrm{pH}$ 8.0; 10 
mM EDTA; 1\% sodium dodecyl sulfate; $0.5 \mathrm{M} \mathrm{NaCl}$ ) was added and the mycelial suspension was ground for 10 to $15 \mathrm{~s}$. The suspension was transferred into a $15-\mathrm{ml}$ centrifuge tube and $3 \mathrm{ml}$ of phenol-chloroform $(1: 1, \mathrm{vol} / \mathrm{vol})$ was added. The tube was shaken vigorously for $30 \mathrm{~s}$, then centrifuged at $12,000 \times g$ for $20 \mathrm{~min}$ at $4^{\circ} \mathrm{C}$. The aqueous phase was transferred to a new centrifuge tube and a second extraction was performed with $3 \mathrm{ml}$ of chloroform. The aqueous phase was transferred to a new centrifuge tube and the nucleic acids were precipitated by the addition of 0.6 volume of isopropanol. The tube was kept at $-20^{\circ} \mathrm{C}$ for $1 \mathrm{~h}$ and then centrifuged at $12,000 \times g$ for $5 \mathrm{~min}$ at $4^{\circ} \mathrm{C}$. The nucleic acid pellet was washed with $5 \mathrm{ml}$ of $70 \%$ ethanol and then vacuum dried. Nucleic acids were resuspended in $200 \mu \mathrm{l}$ of TrisEDTA (TE) buffer (10 mM Tris- $\mathrm{HCl}, 1.0$ mM EDTA; $\mathrm{pH}$ 8.0). The DNA concentration was determined with a fluorometer (model TKO 100; Hoefer Scientific Instruments, San Francisco), and adjusted to a final concentration of $10 \mathrm{ng} / \mu \mathrm{l}$ with $\mathrm{TE}$ buffer.

Random amplified polymorphic DNA analysis and primer design. Random amplified polymorphic DNA (RAPD) analysis was performed with total genomic DNA from four isolates each of $A$. radicina, $A$. dauci, and $A$. alternata using the 20 random primers from Operon primer set A (Operon Technologies, Inc., Alameda, CA). RAPD reactions were carried out in a volume of $50 \mu$ l containing 20 ng DNA, $0.5 \mathrm{mM}$ primer, $0.25 \mathrm{mM}$ of each dNTP, $2.5 \mathrm{mM} \mathrm{MgCl}_{2}$, and $1.0 \mathrm{U}$ of Amplitaq DNA polymerase in $1 \times$ Amplitaq PCR buffer II (PE Applied Biosystems, Foster City, CA). PCR was carried out in a thermal cycler (Model 480; PE Applied Biosystems) programmed for the following parameters: $94^{\circ} \mathrm{C}$ for $1 \mathrm{~min}, 34^{\circ} \mathrm{C}$ for 1.5 min, and $72^{\circ} \mathrm{C}$ for 2 min for 45 cycles. PCR products were fractionated in $1 \%$ agarose gels in Tris-borate-EDTA (TBE) buffer (23) and visualized by UV illumination after staining in ethidium bromide.

RAPD fragments were excised from agarose gels and recovered with silica matrix (GeneClean; Bio 101, Inc., Vista, CA) according to the manufacturer's recommendations. RAPD fragments were cloned with the TA cloning system (Invitrogen, San Diego, CA). DNA sequences were determined using the dideoxynucleotide chain-termination method with Sequenase (USB, Cleveland, $\mathrm{OH}$ ) according to manufacturer's recommendations. Primers were designed using the software OLIGO (ver. 4.0; National Biosciences, Plymouth, MN).

PCR with the $A$. radicina primer pair. The $A$. radicina primer pair was tested for both sensitivity and specificity. To determine sensitivity, 10-fold serial dilutions of A. radicina total genomic DNA were prepared in TE buffer (concentrations ranged from $10 \mathrm{ng} / \mu \mathrm{l}$ to $1 \mathrm{fg} / \mu \mathrm{l})$, and the capacity of the primer pair to direct the amplification of the target DNA fragment from decreasing concentrations of DNA was determined. To determine specificity, the primer pair was tested with total genomic DNA (10 $\mathrm{ng} / \mu \mathrm{l})$ from 13 fungal species (Table 1). In both experiments, PCR was carried out in a volume of $50 \mu \mathrm{l}$ containing $2 \mu \mathrm{l}$ of total genomic DNA, $0.5 \mathrm{mM}$ of each primer, $0.25 \mathrm{mM}$ of each dNTP, 2.5 $\mathrm{mM} \mathrm{MgCl}_{2}$, and $1.0 \mathrm{U}$ of Amplitaq DNA polymerase in $1 \times$ Amplitaq PCR buffer II. PCR was carried out in the Model 480 thermal cycler programmed for the following parameters: $94^{\circ} \mathrm{C}$ for $1 \mathrm{~min}, 60^{\circ} \mathrm{C}$ for $1.5 \mathrm{~min}$, and $72^{\circ} \mathrm{C}$ for $2 \mathrm{~min}$, for 40 cycles. PCR-amplified DNA fragments were fractionated in $1.0 \%$ agarose gels in TBE buffer and visualized by UV illumination after staining in ethidium bromide. These experiments were conducted twice.

Seed assay. For each seed assay, $1.0 \mathrm{~g}$ of carrot seed (approximately 800 to 1,200 seeds) per seed lot was evenly distributed over the bottom of a 100-by-15-mm plastic petri dish. The dish was placed on a rigid mesh support in a plastic box ( 30 by 24 by $10 \mathrm{~cm}$ ) and water was added beneath the mesh support to a depth of $1 \mathrm{~cm}$. A fine mist of sterile water was applied to the seeds in the dish with a spray bottle (approximate duration of misting was 1 to $2 \mathrm{~s})$. After misting, the petri dish cover was replaced slightly ajar and the top was placed over the plastic box to generate conditions of high humidity. The box was incubated in the dark for 5 days at $28^{\circ} \mathrm{C}$.

After incubation, $5 \mathrm{ml}$ of lysis buffer was added to the dish and the dish was rocked to fully moisten all seed and fungal hyphae growing on the seed. The dish was then incubated on a rotary shaker at $60 \mathrm{rpm}$ for $15 \mathrm{~min}$ at $22^{\circ} \mathrm{C}$. The contents of the dish (seeds, mycelia, and lysis buffer) were transferred into a 15-ml centrifuge tube and $3 \mathrm{ml}$ of phenol-chloroform (1:1, $\mathrm{vol} / \mathrm{vol})$ was added. The tube was vigorously shaken for $1 \mathrm{~min}$ and centrifuged at $12,000 \times g$ for $20 \mathrm{~min}$ at $4^{\circ} \mathrm{C}$. The aqueous phase was removed to a new centrifuge tube and a second extraction performed with $3 \mathrm{ml}$ of chloroform. Approximately 3 $\mathrm{ml}$ of aqueous phase was recovered, and $500 \mu \mathrm{l}$ of $10 \%$ polyvinyl-polypyrrolidone was added. The tube was gently rocked on a rotary shaker for $5 \mathrm{~min}$ and then centrifuged at $12,000 \times g$ for $10 \mathrm{~min}$ at $4^{\circ} \mathrm{C}$. Supernatant $(2 \mathrm{ml})$ was removed to a new centrifuge tube and $3 \mathrm{ml}$ of Prep-a-Gene binding buffer (Bio-Rad Laboratories Inc., Hercules, CA) was added. After mixing, $40 \mu$ of Prep-a-Gene DNA binding matrix was added. This solution was incubated for $15 \mathrm{~min}$ at $22^{\circ} \mathrm{C}$, then centrifuged at 12,000 $\times g$ for $1 \mathrm{~min}$. The matrix pellet was washed with $0.5 \mathrm{ml}$ of Prep-a-Gene wash solution and the matrix solution was transferred to a 1.5-ml microfuge tube. The matrix pellet was washed two more times with $0.5 \mathrm{ml}$ of Prep-a-Gene wash solution and then with $0.5 \mathrm{ml}$ of $70 \% \mathrm{EtOH}$. The matrix pellet was dried at $37^{\circ} \mathrm{C}$ overnight. DNA was eluted from the dried matrix by adding $100 \mu \mathrm{l}$ of TE buffer and incubating for $10 \mathrm{~min}$ at $55^{\circ} \mathrm{C}$. After incubation, the microfuge tube was centrifuged at 12,000 $\times g$ for $1 \mathrm{~min}$ and the TE buffer solution containing the seed DNA was recovered.

PCR with DNA recovered from seed was carried out as previously described for total genomic DNA, except that (i) $2 \mu \mathrm{l}$ of seed DNA extract was used and (ii) skim

Table 1. Fungi used in this study

\begin{tabular}{lll}
\hline Species & Isolate & Source $^{\mathbf{a}}$ \\
\hline Alternaria radicina & & \\
type 1 & $21-21-07$ & BMP \\
type 1 & $21-21-11$ & BMP \\
type 2 & $21-21-15$ & BMP \\
type 2 & $21-21-16$ & BMP \\
A. dauci & $21-31-10$ & BMP \\
& $21-31-11$ & BMP \\
& $21-31-15$ & BMP \\
A. alternata & $21-31-16$ & BMP \\
& $21-41-07$ & BMP \\
& $21-41-09$ & BMP \\
A. petroselini & $21-41-10$ & BMP \\
A. smyrnii & $21-41-20$ & BMP \\
A. porri & $09-159$ & EGS \\
A. solani & $37-093$ & EGS \\
A. crassa & 58175 & ATCC \\
A. macrospora & 58177 & ATCC \\
Stemphylium botryosum & Acr1 & DGG \\
S. vesicarium & Ams1 & DGG \\
Ulocladium atrum & 42170 & ATCC \\
U. botrytis & 18521 & ATCC \\
\hline
\end{tabular}

${ }^{a}$ Abbreviations for sources of fungal isolates are as follows: ATCC = American Type Culture Collection, Rockville, MD 20852; BMP = B. M. Pryor, Department of Plant Pathology, University of California, Davis 95616; DGG = D. G. Gilchrist, Department of Plant Pathology, University of California, Davis; EGS = E. G. Simmons, Mycological Services, Crawfordsville, IN 47933. 
milk (Difco Laboratories; $10 \%$ solution in sterile $\mathrm{H}_{2} \mathrm{O}$ ) was added to the PCR reaction mixture to a final concentration of $0.2 \%$ (3). All seed lots were assayed in duplicate and the seed assay experiments were conducted three times. To determine whether the skim milk altered primer sensitivity or specificity, the $A$. radicina primer pair was tested as previously described, except in the presence of $0.2 \%$ skim milk.

To determine the limit of detection of the PCR-based seed assay, samples of a highly infested seed lot (lot D, 41.3\% infestation) were mixed with seed from a noninfested seed lot (lot $\mathrm{H}$ ) at the following proportions (wt/wt) to generate seed lots with the following levels of contamination: $1: 1,20 \% ; 1: 9,4 \% ; 1: 39,1 \%$; $1: 79,0.5 \% ; 1: 159,0.25 \%$; and $1: 399$, $0.1 \%$. Each seed lot was assayed in duplicate and the experiment was conducted twice.

\section{RESULTS}

RAPD analysis and primer design. generated distinct RAPD patterns from total genomic DNA of $A$. radicina, $A$. dauci, and A. alternata. Comparison of the RAPD patterns generated with primer A20 revealed an approximately $1.2-\mathrm{kb}$ fragment that was amplified from total genomic DNA of $A$. radicina isolates but not from that of the A. dauci or A. alternata isolates (Fig. 1). This putative $A$. radicina-specific RAPD fragment was cloned from isolate 21-21-07. Plasmid pAr07207, which contains the $1.2-\mathrm{kb}$ A. radicina RAPD fragment, was selected for further characterization. Southern blot hybridization analysis experiments, in which pAr07207 was used as a probe and hybridized with RAPD fragments generated from A. radicina, $A$. dauci, and $A$. alternata, confirmed that the Seventeen of the Operon set A primers 1.2-kb A. radicina RAPD fragment had been cloned and that this RAPD fragment did not hybridize with other RAPD fragments generated from these fungi with primer A20 (data not shown).

The nucleotide (nt) sequences (approximately 150 to $200 \mathrm{nts}$ ) of each end of the cloned RAPD fragment were determined (data not shown). From these sequences, an A. radicina primer pair (Pa2071, 5'GGGCGTTATGCGAGATCAGG-3'; and Pa2072, 5'-GTATTTGTAGGAATTTCCAG$\left.3^{\prime}\right)$ was designed.

Sensitivity and specificity of the $A$. radicina primer pair. The $A$. radicina primer pair directed the amplification of an approximately 900-bp DNA fragment from total genomic DNA of $A$. radicina types 1 and 2 . In sensitivity tests with serial dilutions of $A$. radicina total genomic DNA, the limit of detection (i.e., the lowest concentration of total genomic DNA from which the target fragment was amplified) for the $A$. radicina primer pair was $200 \mathrm{fg}$ (Fig. 2). In specificity tests with total genomic DNA from 12 other fungal species, the $A$. radicina primer pair directed the amplification of an approximately 900bp DNA fragment from total genomic DNA of $A$. petroselini and A. smyrnii, parsley, and celery pathogens that are closely related to $A$. radicina (25). No DNA fragments were amplified from total genomic DNA of the other 10 fungal species (Fig. 3).

Seed assay. In initial PCR assays conducted with the $A$. radicina primer pair and DNA extracts prepared from A. radicinacontaminated seed lots, the target DNA sequence was not amplified. When $A$. radicina total genomic DNA (10 $\mathrm{ng} / \mu \mathrm{l})$ was added into the seed DNA extracts (1:1, vol/vol) and the PCR repeated, the target DNA sequence still was not amplified. However, if the DNA extracts were diluted
1:9 or 1:99 with TE buffer ( $\mathrm{vol} / \mathrm{vol})$, the target sequence was amplified. Together, these results suggested that the PCR inhibitors were present in the DNA extracts prepared from seed. When $0.2 \%$ skim milk was included in the PCR mixture, the target $A$. radicina DNA sequence was consistently amplified from undiluted DNA extracts prepared from infested seed.

In experiments to determine if skim milk altered the sensitivity of the primer pair, the limit of detection was $2 \mathrm{pg}$ of total genomic DNA (data not shown). The specificity of the A. radicina primer pair was not affected by the presence of skim milk.

With skim milk in the PCR, the $A$. radicina primer pair directed the amplification of the target DNA sequence from undiluted DNA extracts prepared from naturally infested seed lots having infestations rates ranging from 41 to $0.3 \%$ (Fig. 4). No DNA fragments were amplified from equivalent extracts prepared from noninfested seed lots (Fig. 4). Similar results were obtained for three independent experiments.

In experiments to determine the limit of detection (sensitivity) of the $A$. radicina seed assay (i.e., the lowest level of seed contamination that could be detected), the target DNA sequence was amplified from the duplicate samples of undiluted DNA extracts from seed lots having 20,4,1, 0.5, and $0.25 \%$ infestation, and from one of the two samples from the seed lot with $0.1 \%$ contamination (Fig. 5). In a second independent experiment, the target DNA sequence was amplified from duplicate samples of undiluted DNA extracts from seed lots having $20,4,1$, and $0.5 \%$ infestation, and from one of the two samples from the seed lots with $0.25 \%$ and $0.1 \%$ infestation (data not shown).
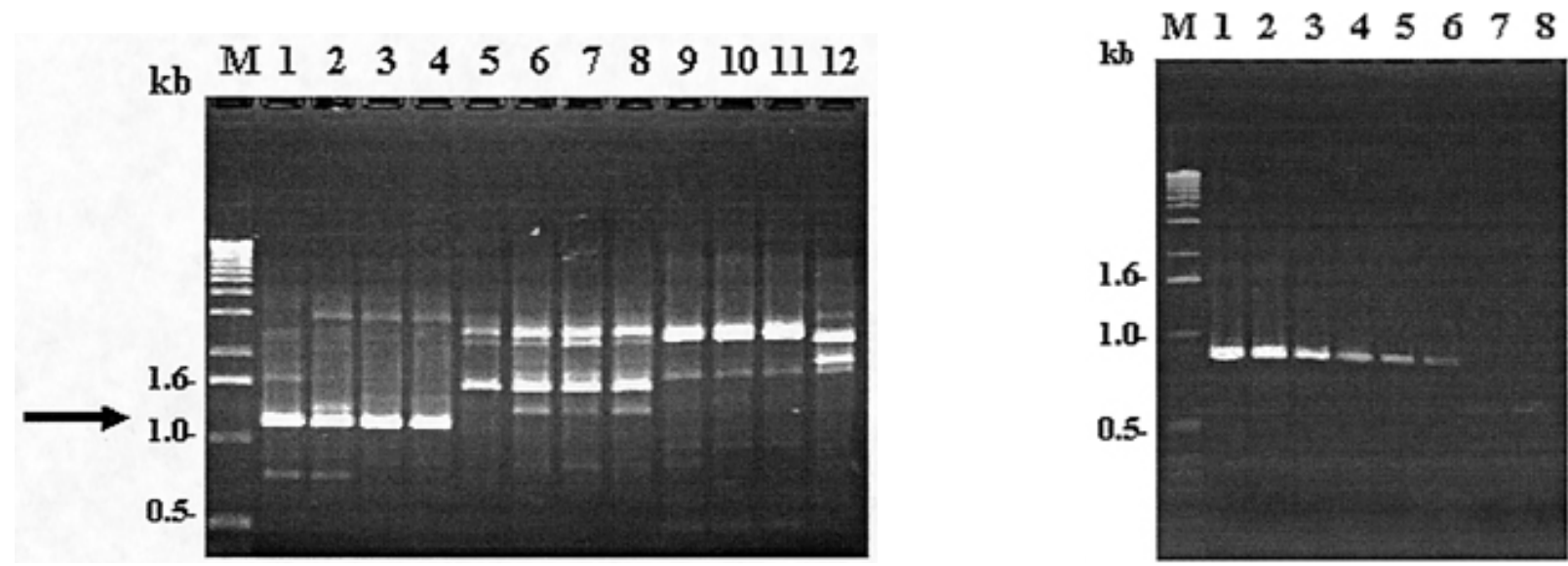

Fig. 1. Random amplified polymorphic DNA patterns generated from total genomic DNA of Alternaria radicina, A. dauci, and A. alternata with Operon primer A20. Lanes 1 and 2, A. radicina type 1 (isolates 21-21-07 and 21-21-11, respectively); lanes 3 and 4, A. radicina type 2 (isolates 21-21-13 and 21-21-16, respectively); lanes 5 to 8, A. dauci (isolates 21-31-10, 21-31-11, 21-31-15, and 2131-16, respectively); lanes 9 to 12, A. alternata (isolates 21-41-07, 21-41-09, 21-41-10, and 21-4114, respectively). Lane M contains the 1-kb DNA ladder (Gibco BRL, Gaithersburg, MD). The arrow indicates the RAPD fragment that was cloned and partially sequenced for the development of the $A$. radicina primer pair.
Fig. 2. Limit of detection of the Alternaria radicina primer pair. The primer pair was used in the polymerase chain reaction with serial dilutions of $A$. radicina total genomic DNA. Lanes 1 to 8 contain $20 \mathrm{ng}, 2 \mathrm{ng}, 200 \mathrm{pg}, 20 \mathrm{pg}$, $2 \mathrm{pg}, 200 \mathrm{fg}, 20 \mathrm{fg}$, and $2 \mathrm{fg}$ of total genomic DNA, respectively. Lane $M$ contains the $1-\mathrm{kb}$ DNA ladder (Gibco BRL, Gaithersburg, MD). 


\section{DISCUSSION}

The PCR-based assay developed for detection of $A$. radicina on carrot seed represents the results of numerous experiments aimed at optimizing parameters to allow for reliable PCR-based detection of this fungus from infested seed. Two major obstacles had to be overcome in the development of this assay: (i) low levels of the fungus (i.e., target DNA) associated with seed and (ii) PCR inhibitors associated with carrot seed. Seed infested with fungi often occurs at very low infestation levels, and DNA extracts prepared from this seed will contain low levels of the target DNA sequence. To overcome this problem, a preassay incubation step was used to increase fungal biomass on seeds. A preassay incubation step also was used in the PCRbased assay for detection of Leptosphaeria spp. from rapeseed (28). In the development of PCR-based seed assays for other fungi, it may be necessary to use similar preassay incubation steps in order to increase the amount of target fungus on seed.

A variety of incubation methods were tested to facilitate rapid and consistent growth of $A$. radicina on carrot seed, including incubating seed in liquid culture, in culture tubes, or on moistened filter paper. Although some of these methods allowed for growth of $A$. radicina on seed, PCR amplification of the target $A$. radicina DNA sequence from DNA extracts prepared from this seed was inconsistent, even for highly infested seed lots. In many cases, bacteria overgrew or suppressed fungal growth, and the addition of antibiotics failed to suppress bacterial growth and to improve the reliability of the PCR assay. However, when seeds were simply placed on the surface of a plastic petri dish, in the absence of nutrients but under conditions of high humidity, abundant fungal growth developed on the seed surface with little or no bacterial growth. This preassay incubation method produced sufficient fungal growth for the consistent recovery of fungal genomic DNA from which the target DNA sequence could be amplified. Furthermore, $1 \mathrm{~g}$ of seed (approximately 800 to 1,000 seeds) could be assayed in a single 100-by-15-mm petri dish. Larger amounts of seed (e.g., 10,000) could be assayed by increasing the number of petri dishes or possibly by using larger-sized dishes.

PCR inhibitors associated with carrot seed were another obstacle in the development of this assay. Such inhibitors have been commonly encountered in the development of PCR assays for the detection of organisms or DNA from complex environmental samples $(3,9)$. In the present study, these inhibitors appeared to come from carrot seed because (i) inhibitors were not associated with fungal DNA extracted from mycelia and (ii) inhibitors were consistently encountered in DNA extracts from carrot seed, irrespective of whether it was contaminated with Alternaria spp. or other fungi. Thus, it was necessary to develop a method for recovering fungal hyphae from seed while minimizing the release of PCR inhibitors from seed. Again, a variety of methods were tested, but these either failed to generate sufficient amounts of fungal DNA or disrupted seed tissue, resulting in the release of PCR inhibitors. By adding lysis buffer directly to seeds after incubation, followed by a phenol-chloroform extrac- tion of the total sample (i.e., buffer, mycelia, and seeds), a sufficient amount of fungal DNA was recovered with a minimal amount of PCR inhibitors.

DNA recovered from seed after phenolchloroform extraction and ethanol precipitation contained brown pigments (e.g. phenolics) and PCR inhibitors that could not be removed by repeated washing with $70 \%$ ethanol or repeated DNA precipitation. To reduce these contaminants, silica matrix (i.e., the Prep-a-Gene Purification

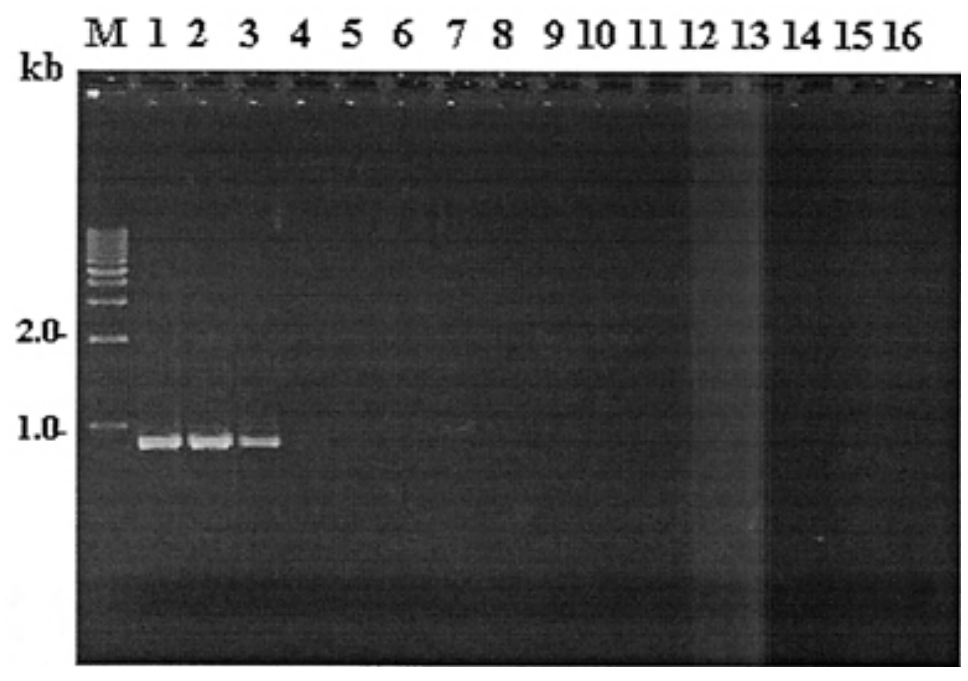

Fig. 3. Specificity of the Alternaria radicina primer pair. The primer pair was used in the polymerase chain reaction with total genomic DNA (20 ng) of various fungal species. Lanes 1 to 16 represent Alternaria radicina, A. petroselini, A. smyrnii, A. japonica, A. cheiranthi, A. dauci, A. solani, A. porri, A. macrospora, A. crassa, A. alternata, A. brassicae, Ulocladium atrum, U. botrytis, Stemphylium botryosum, and $S$. vesicarium, respectively. Lane $\mathbf{M}$ contains the 1-kb DNA ladder (Invitrogen, Carlsbad, CA).

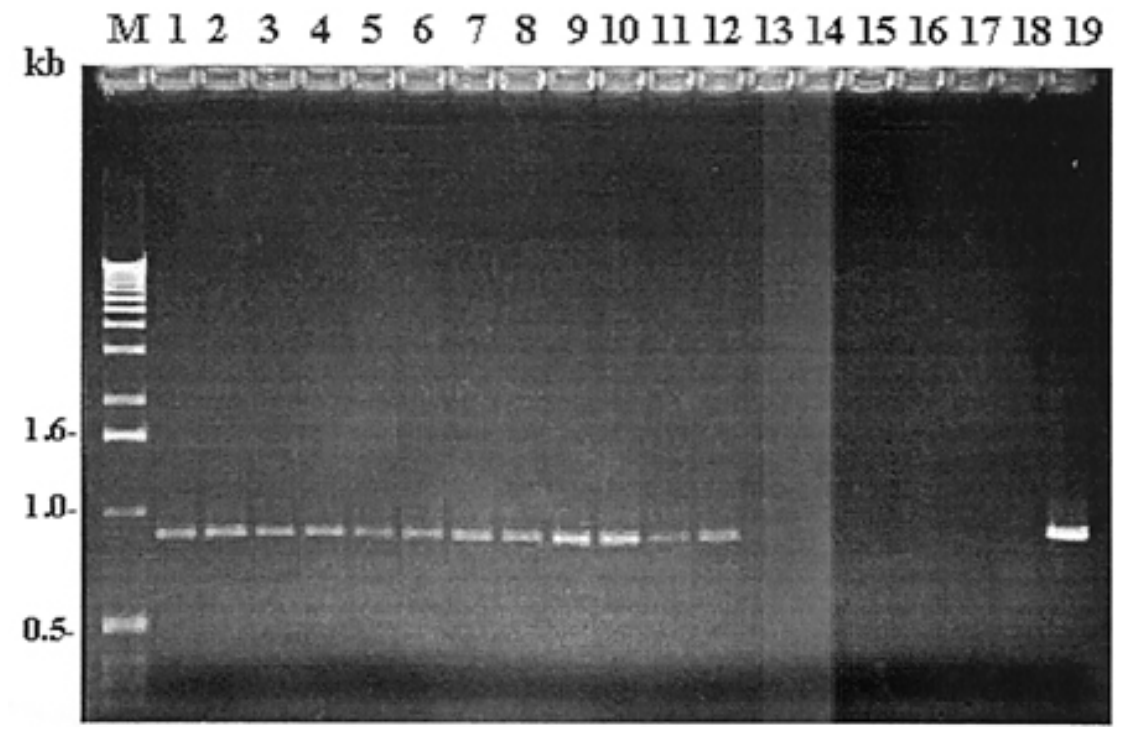

Fig. 4. Detection of Alternaria radicina from naturally infested carrot seed lots with the polymerase chain reaction-based seed assay. Lanes 1 to 18 show results of two independent extractions for each seed lot having the indicated rates of $A$. radicina infestation: lanes 1 and 2, seed lot A (1.0\%); lanes 3 and 4, seed lot B (11.5\%); lanes 5 and 6, seed lot C (8.0\%); lanes 7 and 8, seed lot D (41.3\%); lanes 9 and 10, seed lot E (6.5\%); lanes 11 and 12, seed lot F (0.3\%); lanes 13 and 14, seed lot G $(0.0 \%)$; lanes 15 and 16, seed lot $\mathrm{H}(0.0 \%)$; and lanes 17 and 18 , seed lot $\mathrm{I}(0.0 \%)$. Lane 19 is a positive control showing the amplification of the approximately 900-bp target DNA fragment amplified from A. radicina total genomic DNA. Lane M contains the 1-kb DNA ladder (Gibco BRL, Gaithersburg, MD). 
kit) was used instead of ethanol precipitation to recover DNA. DNA recovered with silica matrix did not contain brown pigments and, after a 1:10 dilution, the target DNA sequence was consistently amplified from seed DNA extracts. However, the fact that it was necessary to dilute this DNA for consistent amplification of the target DNA sequence indicated that some PCR inhibitors were still present. The addition of skim milk to the PCR reaction allowed for the consistent amplification of the target DNA fragment from undiluted DNA extracts from seed. The use of skim milk to overcome PCR inhibitors has been previously described, although the mechanism by which this occurs is not known (3).

The $A$. radicina primer pair was not species-specific (i.e., this primer pair also directed the amplification of an approximately 900-bp DNA fragment from the celery and parsley pathogens $A$. petroselini and $A$. smyrnii). However, this should not result in false positives in carrot seed assays because these fungi are not associated with carrot seed $(16,25)$. Alternatively, a more specific $A$. radicina primer pair could be developed. New primer pairs can easily be incorporated into this PCR-based assay, thereby providing a means for continually updating and improving the specificity and sensitivity of the assay.

The PCR-based assay developed for the detection of $A$. radicina on infested carrot seed is accurate, sensitive, and reliable. Because it has the 5-day incubation period, this test requires approximately 6 days to complete, compared with 10 days for the freezer-blotter test. Another advantage of the PCR-based assay is that is does not rely on visual identification of $A$. radicina on carrot seed, which is complicated by the frequent occurrence of morphologically similar saprobes on carrot seed. Thus, this PCR-based assay has the potential to be used for routine testing of carrot seed lots for A. radicina. Furthermore, this type of test may have applicability for the detection of other fungal pathogens on seed of other crops, once appropriate primer pairs are developed.

\section{ACKNOWLEDGMENTS}

We thank J. van Bilsen of Bejo Seeds for supplying many of the seed lots used in this study.

\section{LITERATURE CITED}

1. Audy, P., Braat, C. E., Saindon, G., Huang, H. C., and Laroche, A. 1996. A rapid and sensitive PCR-based assay for concurrent detection of bacteria causing common and halo blights in bean seed. Phytopathology 86:361-366.

2. Bariana, H. S., Shannon, A. L., Chu, P. W. G., and Waterhouse, P. M. 1994. Detection of five seedborne legume viruses in one sensitive multiplex polymerase chain reaction test. Phytopathology 84:1201-1205.

3. De Boer, S. H., Ward, L. J., Li, X., and Chittaranjan, S. 1995. Attenuation of PCR inhibition in the presence of plant compounds by addition of BLOTTO. Nucleic Acids Res. 23:2567-2568.

4. Ellis, M. B., and Holliday, P. 1972. Alternaria radicina. No 346. CMI Descriptions of Pathogenic Fungi and Bacteria. Commonw. Mycol. Inst., Kew, U.K

5. Grogan, R. G., and Snyder, W. C. 1952. The occurrence and pathological effects of Stemphylium radicinum on carrots in California. Phytopathology 42:215-218.

6. Groves, J. W., and Skolko, A. J. 1944. Notes on seed-borne fungi; II. Alternaria. Can. J. Res. 22: 219-234.

7. Hewitt, P. D. 1964. Testing carrot seed infected with Alternaria porri f. sp. dauci. Proc. Int. Seed Test. Assoc. 29:463-471.

8. International Seed Testing Association. 1966. International rules for testing, 1966. Proc. Int. Seed Test. Assoc. 31:1-152.

9. Jobes, D. V., Hurley, D. L., and Thien, L. B. 1995. Plant DNA isolation: a method to effi-

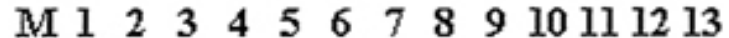

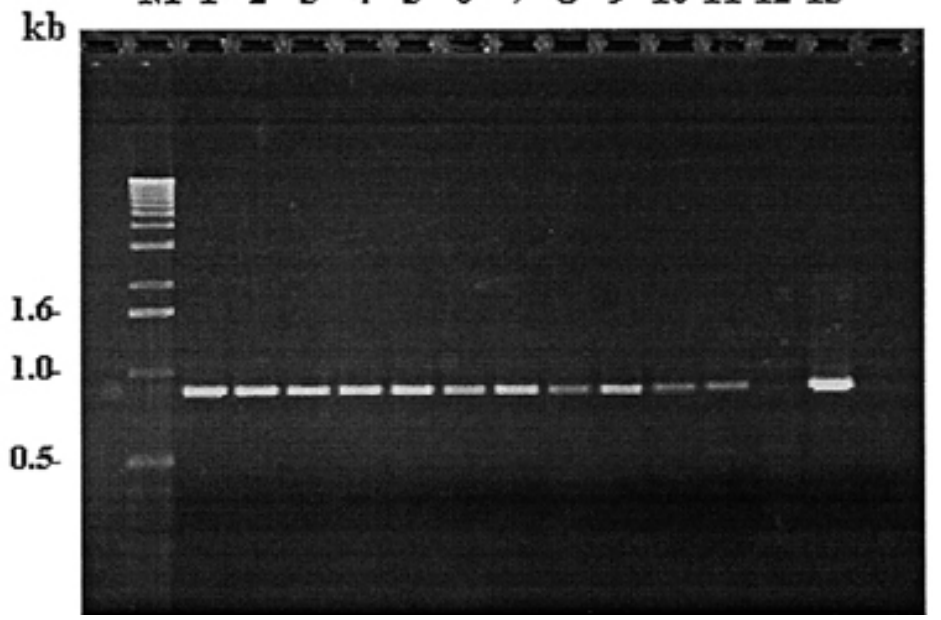

Fig. 5. Detection of Alternaria radicina from carrot seed lots having different levels of infestation with the polymerase chain reaction-based seed assay. Lanes 1 to 12 show results from two independent DNA extractions for each seed lot having the indicated rates of A. radicina infestation: lanes 1 and 2, 20\%; lanes 3 and 4, 4\%; lanes 5 and 6, 1\%; lanes 7 and 8, 0.5\%; lanes 9 and 10,0.25\%; and lanes 11 and 12, $0.1 \%$. Lane 13 is a positive control showing the amplification of the approximately 900-bp target DNA fragment amplified from A. radicina total genomic DNA. Lane M contains the 1kb DNA ladder (Gibco BRL, Gaithersburg, MD) ciently remove polyphenolics, polysaccharides, and RNA. Taxon 44:379-386.

10. Lauritzen, J. I. 1926. The relation of black rot to the storage of carrots. J. Agric. Res. 33:1025-1041.

11. Maes, M., Garbeva, P., and Kamoen, O. 1996. Recognition and detection in seed of the Xanthomonas pathogens that cause cereal leaf streak using rDNA spacer sequences and polymerase chain reaction. Phytopathology 86:63-69.

12. Maude, R. B. 1966. Studies on the etiology of black rot, Stemphylium radicinum (Meier, Drechsl., \& Eddy) Neerg., and leaf blight, Alternaria dauci (Kühn) Groves \& Skolko, on carrot crops; and on fungicide control of thei seed-borne infection phases. Ann. Appl. Biol. 57:83-93

13. Maude, R. B., and Shuring, C. G. 1972. Black rot of carrots. Rep. Natl. Veg. Res. Stn. 20:103.

14. Meier, F. C., Drechsler, C., and Eddy, E. D. 1922. Black rot of carrots caused by Alternaria radicina $\mathrm{N}$. sp. Phytopathology 12:157168.

15. Murtaza, M., Wahid, A., Ali, S., and Nadeem, A. 1988. Seedling blight of carrots caused by Stemphylium radicinum. Pak. J. Agric. Res. 9:601-603

16. Neergaard, P. 1945. Danish Species of Alternaria and Stemphylium. Oxford University Press, London.

17. Neergaard, P. 1977. Seed Pathology, Volume I. Halsted Press, New York.

18. Phan, T. T. H., Khetarpal, R. K., Le, T. A. H., and Maury, Y. 1997. Comparison of immunocapture PCR and ELISA in quality control of pea seed for pea seedborne mosaic potyvirus. In: Seed Health Testing: Progress Towards the 21st Century. Cambridge Agric. Bur. Int Wallingford, U.K

19. Pryor, B. M., Davis, R. M., and Gilbertson, R L. 1994. Detection and eradication of Alternaria radicina on carrot seed. Plant Dis. 78:452-456.

20. Pryor, B. M, Davis, R. M., and Gilbertson, R. L. 1997. Phenotypic and molecular characterization of Alternaria radicina; a review of the species. (Abstr.) Inoculum 48:31.

21. Pryor, B. M., Davis, R. M., and Gilbertson, R. L. 1997. Detection of soilborne A. radicina and its occurrence in California carrot fields. Plant Dis. 82:891-895.

22. Pryor, B. M., and Gilbertson, R. L. 1999. Development of a PCR-based assay for the detection of Alternaria radicina from infested carrot seed. (Abstr.) Phytopathology 89:S61

23. Sambrook, J. Fritsch, E. F., and Maniatis, T. 1989. Molecular Cloning: A Laboratory Manual (3). Cold Spring Harbor Laboratory Press, Cold Spring Harbor, NY.

24. Scott, D. J., and Wenham, H. T. 1972. Occurrence of two seed-borne pathogens, Alternaria radicina and Alternaria dauci, on imported carrot seed in New Zealand. N.Z. J. Agric. Res. 16:247-250.

25. Simmons, E. G. 1995. Alternaria themes and variations (112-144). Mycotaxon 55:55-163.

26. Smith, O. P., Peterson, G. L., Beck, R. J., Schaad, N. W., and Bonde, M. R. 1996. Development of a PCR-based method for identification of Tilletia indica, causal agent of Karnal bunt of wheat. Phytopathology 86:115-122.

27. Soteros, J. J. 1979. Detection of Alternaria radicina and $A$. dauci from imported carrot seed in New Zealand. N. Z. J. Agric. Res. 22:185-190.

28. Taylor, J. L. 1993. A simple, sensitive, and rapid method for detection of seed contaminated with highly virulent Leptosphaeria maculans. Appl. Environ. Microbiol. 59: 3681-3685. 
29. Tylokowska, K. 1992. Carrot seed-borne diseases caused by Alternaria species. In: Alternaria Biology, Plant Diseases and Metabolites. J. Chelkowski and A. Visconti, eds. Elsevier Science Publishers B. V., Amsterdam. 30. Umesh, K. C., Davis, R. M., and Gilbertson,
R. L. 1996. Seed contamination thresholds associated with occurrence of bacterial blight of carrots and development of a DNA based detection method for Xanthomonas campestris pv. carotae. (Abstr.) Phytopathology 86:S11. 31. Vlugt, R. A. A. van der, Berendsen, M.,
Koenraadt, H., Hutchins, J. D., and Reeves, J. C. 1997. Immunocapture reverse transcriptase PCR for the detection of lettuce mosaic virus. In: Seed Health Testing: Progress Towards the 21st Century. Cambridge Agric. Bur. Int. Wallingford, U.K 